\title{
Socio-demographic Structure of the Border Area in the Northwest Part of Republic of Srpska
}

\author{
Marijanac, Z.*, Đurđev, B.* ${ }^{* *}$ Marinković, $D .^{*}$
}

Albstract The paper deals with socio-demographic problems and structures in the border zone of the northwest part of Republic of Srpska as the effects of ethnic, religious and civil war (1992-1995). Main points are: Recent demographic process which follows the decline of birth rate and the increase of emigration; $\mathrm{Mi}$ grations during and after the war; Perspective and future of population living in border zone of the northwest part of Republic of Srpska.

Key words demographic problems, population, Republic of Srpska, structures, demographic perspective $\sqcap$ he territory of Republic of Srpska has an unusual shape. It includes north and east part of Bosnia and Herzegovina. According to Dayton agreement, the area of Republic of Srpska is $25053.11 \mathrm{~km}^{2}$, i.e. $49 \%$ of the total area of Bosnia and Herzegovina. Curved and elongated shape, with many narrow parts, makes it difficult to maintain smooth communication and economic integration between south and west parts of Republic of Srpska. However, despite all difficulties, Republic of Srpska has territorial integrity and it functions as an integral administrative unit. It should also be pointed out that this are has transit function in communication between West Europe and Adriatic Sea.

The north part of Republic of Srpska lies on the west - east axis, while the east part stretches along the north south axis. The border is disproportionally long compared to dimension of the area. The Republic of Srpska borders on FR Yugoslavia and Republic of Croatia (internationally recognized borders) and on Federation of Bosnia and Herzegovina (border between two entities, recognized in Dayton). The total length of the border of Republic of Srpska is $2177 \mathrm{~km}$ (1081 km borders on the entity), which is longer than the whole border of Bosnia and Herzegovina (1537 km). The degree in which the border is jagged, i.e. the ratio between actual and minimal length, is 3.6 , which is a rare example in the world. Strategic depth of the territory is very small, while some towns (e.g. Novi Grad, Kozarska Dubica) are located on the very border of state territory.

According to the research of Bureau for Statistics of Republic of Srpska, done in 2000, Republic of Srpska has 1,469,182 inhabitants, i.e. 58.6 inhabitant/ $\mathrm{km}^{2}$, which ranks it among densely pop-

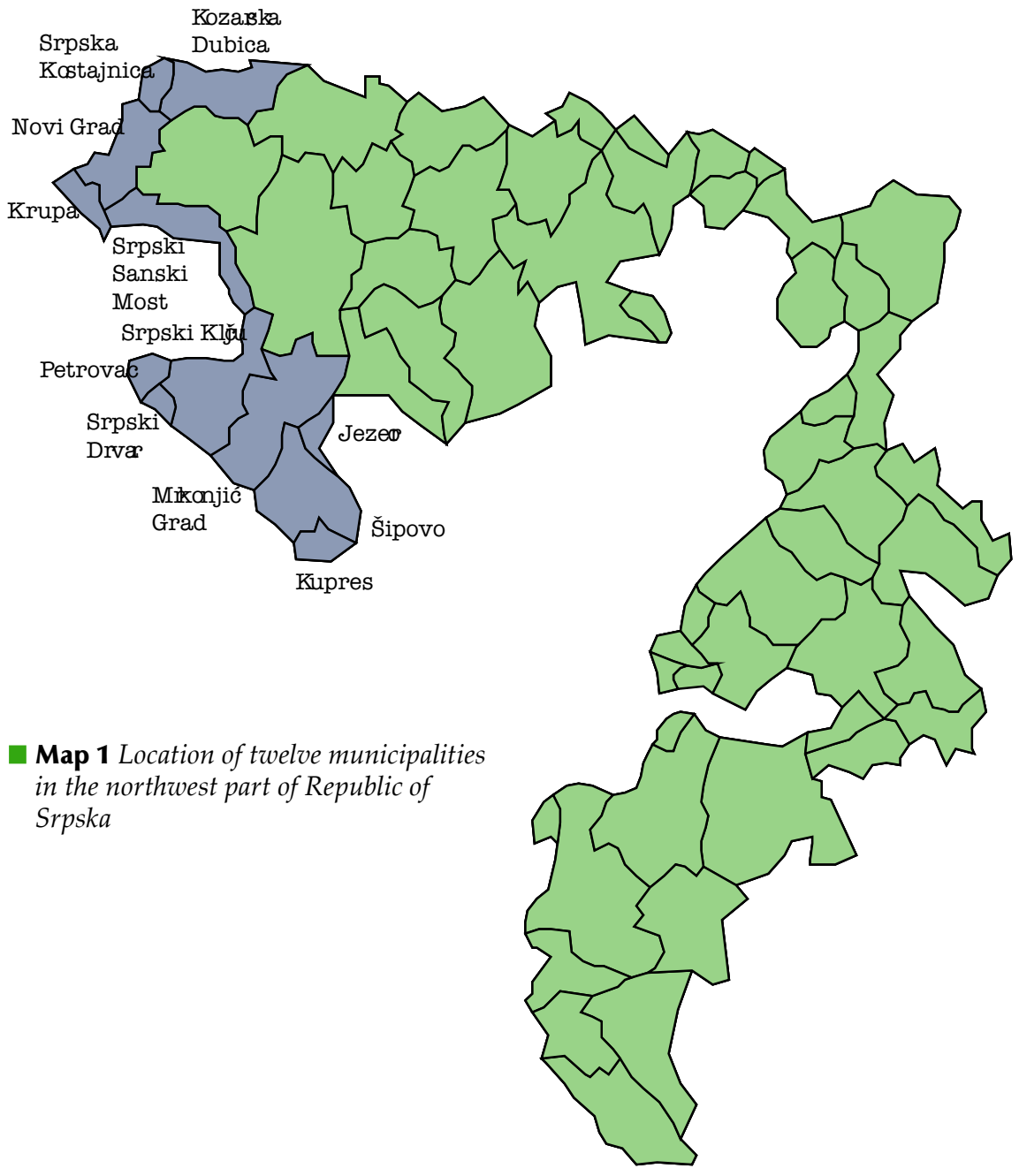

Zdravko Marijanac, Draško Marinković, Faculty of Natural Sciences, University of Banja Luka

** Branislav S. Đurđev, University in Novi Sad, Faculty of Natural Sciences, Institute of Geography, Tourismology and Hotel Management, Trg Dositeja Obradovića 3, 21000 Novi Sad, Yugoslavia 
Table 1 Area, population number and population density of twelve municipalities in the northwest part of Republic of Srpska, in 1996 and 2000

\begin{tabular}{|c|c|c|c|c|c|c|c|}
\hline \multirow{2}{*}{$\begin{array}{l}\text { Ordinal } \\
\text { number }\end{array}$} & \multirow{2}{*}{ Municipality } & \multirow{2}{*}{ Area in $\mathrm{km}^{2}$} & \multicolumn{2}{|c|}{ Population number } & \multicolumn{2}{|c|}{ Population number per $\mathrm{km}^{2}$} & \multirow{2}{*}{$\begin{array}{l}\text { Number of } \\
\text { settlements }\end{array}$} \\
\hline & & & 1996 & 2000 & 1996 & 2000 & \\
\hline 1. & Kozarska Dubica & 499,00 & 33.289 & 34.110 & 66,7 & 68,3 & 61 \\
\hline 2. & Srpska Kostajnica & 86,17 & 7.467 & 7.672 & 86,6 & 89,0 & 12 \\
\hline 3. & Novi Grad & 467,83 & 28.502 & 30.197 & 60,9 & 64,5 & 48 \\
\hline 4. & Krupa na Uni & 93,13 & 1.615 & 1.852 & 17,3 & 19,8 & 13 \\
\hline 5. & Srpski Sanski Most & 203,60 & 2.463 & 3.081 & 12,1 & 15,1 & 24 \\
\hline 6. & Srpski Ključ & 507,44 & 7.881 & 8.669 & 15,5 & 17,1 & 29 \\
\hline 7. & Petrovac & 144,87 & 15 & 64 & 0,1 & 0,4 & 3 \\
\hline 8. & Srpski Drvar & 74,25 & 3 & 31 & 0,04 & 0,4 & 5 \\
\hline 9. & Mrkonjić Grad & 662,29 & 16.088 & 18.898 & 24,3 & 28,5 & 41 \\
\hline 10. & Šipovo & 534,1 & 7.973 & 9.850 & 14,9 & 18,4 & 44 \\
\hline 11. & Srpski Kupres & 45,45 & 5 & 188 & 0,1 & 4,1 & 5 \\
\hline 12. & Jezero & 64,75 & 533 & 1.078 & 8,2 & 16,6 & 12 \\
\hline \multicolumn{2}{|l|}{ Total } & $3.382,88$ & 105.834 & 115.690 & 27,8 & 28,5 & 297 \\
\hline \multicolumn{2}{|c|}{ in \% of Republic of Srpska } & $13,5 \%$ & $7,6 \%$ & $7,9 \%$ & - & - & $11,3 \%$ \\
\hline \multicolumn{2}{|c|}{ Republika Srpska } & $25.053,11$ & 1.391 .593 & 1.469 .182 & 55,1 & 58,6 & 2622 \\
\hline
\end{tabular}

\section{Source $9 \mathcal{E} 10$}

ulated areas. However, the average population density does not give us the real picture of the area. This is because the inner parts of the area, especially cities and towns, are much more populated than the border zones. To explain this fact, there are a great number of both natural and social reasons, of which demographic factor seem to be the most important one. Thus, the following part of the paper deals with some demographic problems and processes within border zone of the northwest part of Republic of Srpska (Map 1).

\section{Population}

Border zone of the northwest part of Republic of Srpska includes the following municipalities: Kozarska Dubica, Srpska Kostajnica, Novi Grad (those three bordering on Croatia), Krupa na Uni, Srpski Sanski Most, Srpski Ključ, Srpski Petrovac, Srpski Drvar, Mrkonjić Grad, Šipovo, Srpski Kupres and Jezero (bordering on Federation of Bosnia and Herzegovina). Municipalities of Srpska Kostajnica and Jezero were formed after the agreement in Dayton, while the rest of them existed in former SR Bosnia and Herzegovina. Today, larger part of some of these municipalities (Krupa na Uni, Srpski Sanski Most, Srpski Ključ, Srpski Petrovac, Srpski Drvar and Srpski Kupres) belongs to Federation of Bosnia and Herzegovina. The border length is $312 \mathrm{~km}$ (66 km with Croatia and $246 \mathrm{~km}$ with Federation of B. and H.), which is $14.3 \%$ of the border length of Republic of Srpska or 20.3\% of border length of Bosnia and Herze- govina. Territory of these twelve municipalities covers the area of 3,382.88 $\mathrm{km}^{2}$, which is $13.5 \%$ of the area of Republic of Srpska. According to the 2000 census, this territory has 115,690 inhabitants, i.e. $7.9 \%$ of the total population of Republic of Srpska. The average population density is 28.5 inhab. $/ \mathrm{km}^{2}$, which makes a half of the Republic average. The territory includes 297 settlements, i.e. $11.3 \%$ of the total number of settlements in Republic of Srpska. The overview of population number (in 1996 and 2000), population density, number of settlements and municipal area is given in Table 1 .

The municipality of Mrkonjić Grad has the largest area $\left(662.29 \mathrm{~km}^{2}\right)$, while Srpski Kupres has the smallest one $\left(45.45 \mathrm{~km}^{2}\right)$. The largest population number is in Kozarska Dubica $(34,110$ inhabitants) and the smallest one in Srpski Drvar (31 inhab.). The highest population density is found in Srpska Kostajnica $\left(89.0\right.$ inhab. $\left./ \mathrm{km}^{2}\right)$, and the lowest one in Petrovac and Srpski Drvar (0.4 inhab./ $\mathrm{km}^{2}$ ).

Comparing the data from 1996 with those from 2000, we can see that there is a slight increase in population number on this territory (Table 2). However, this is not the result of natural population increase, but rather of a gradual process in which refugees return to their homes. The rate of natural increase was negative both in 1996 and 2000. In 1996, positive natural increase was recorded in two municipalities and, in 2000, in four of them. This territory used to have higher natality rate than other parts of the present Republic of Srpska. In 1996 and 2000, the natality rate was lower than the average for the whole Republic. We should pay attention to the mortality rate which is also increasing: between 1996 and 2000, the total number of deaths was raised for almost $1 / 3$. Mortality rate was reduced in three municipalities: Novi Grad, Krupa na Uni and Srpski Kupres. Comparing to situation in whole Republic, the mortality rate in these municipalities is above the average. It is intriguing that $24.9 \%$ of deaths in 2000 were filed as "unknown" or "other", regarding the cause of death. This percentage in the Republic is $20.4 \%$. However, most frequent causes of deaths are diseases of the circulatory system, diseases of the respiratory system and neoplasms which caused $66.3 \%$ of all deaths in 2000; in Republic this percentage was $69.9 \%$ (Graph 1).

In table 3, which shows ethno-demographic structure, we can see that Serbs are the majority in eight, out of ten, municipalities, which existed on this territory in the former SR Bosnia and Herzegovina. With regard to total number of population on this territory, Serbs make up $54.5 \%$, Muslims 38.4\%, Croats 3.7\% and others $3.4 \%$ of population. In the former municipality Titov Drvar, the Serbs make up $97.3 \%$ of population, in Sipovo $79.2 \%$, in Mrkonjić Grad 77.3\%, in Bosanski Petrovac $75.3 \%$, in Bosanska Dubica $69.1 \%$, in Bosanski Novi $60.4 \%$, etc. The table shows that Serbs are majority in most settlements.

With regards to land ownership, Serbs own much more land than other nations in nine out of ten municipalities. We should also point out that Cro- 
Table 2 Natural aspect of population changes in twelve municipalities in the northwest part of Republic of Srpska, for 1996 and 2000

\begin{tabular}{|c|c|c|c|c|c|c|c|c|c|c|c|c|c|c|c|}
\hline \multirow{2}{*}{$\begin{array}{l}\text { Ordinal } \\
\text { number }\end{array}$} & \multirow[b]{2}{*}{ Municipality } & \multirow{2}{*}{$\begin{array}{c}\text { Population } \\
\text { number in } \\
1996\end{array}$} & \multicolumn{2}{|c|}{ Live births } & \multicolumn{2}{|c|}{ Deaths } & \multicolumn{2}{|c|}{ Natural increase } & \multirow{2}{*}{$\begin{array}{c}\text { Population } \\
\text { number in } \\
2000\end{array}$} & \multicolumn{2}{|c|}{ Live births } & \multicolumn{2}{|c|}{ Deaths } & \multicolumn{2}{|c|}{ Natural increase } \\
\hline & & & number & $\%$ & number & $\%$ & number & $\%$ & & number & $\%$ & number & $\%$ & number & $\%$ \\
\hline 1. & Koz.Dubica & 33.289 & 205 & 6,1 & 248 & 7,4 & -43 & $-1,3$ & 34.110 & 261 & 7,6 & 296 & 8,7 & -35 & $-1,1$ \\
\hline 2. & S.Kostajnica & 7.467 & 57 & 7,6 & 67 & 8,9 & -10 & $-1,3$ & 7.672 & 51 & 6,6 & 74 & 9,6 & -23 & $-3,0$ \\
\hline 3. & Novi Grad & 28.502 & 262 & 9,2 & 305 & 10,7 & -43 & $-1,5$ & 30.197 & 258 & 8,5 & 288 & 9,5 & -30 & $-1,0$ \\
\hline 4. & Krupa na Uni & 1.615 & 8 & 4,9 & 31 & 19,1 & -23 & -14 & 1.852 & 12 & 6,5 & 19 & 10,3 & -7 & $-3,8$ \\
\hline 5. & S.S.Most & 2.463 & 10 & 4,0 & 4 & 1,6 & 6 & 2,4 & 3.081 & 75 & 24,3 & 41 & 13,3 & 34 & 11,0 \\
\hline 6. & S.Ključ & 7.881 & 30 & 3,8 & 71 & 9,0 & -41 & $-5,2$ & 8.669 & 95 & 11,0 & 129 & 14,9 & -34 & $-3,9$ \\
\hline 7. & Petrovac & 15 & - & - & - & - & - & 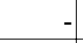 & 64 & 2 & 31,3 & 10 & 15,6 & -8 & -125 \\
\hline 8. & S.Drvar & 3 & - & - & - & - & - & - & 31 & 1 & 32,3 & 2 & 64 & -1 & -32 , \\
\hline 9. & Mrkonj. Grad & 16.088 & 140 & 8,7 & 110 & 6,8 & 30 & 1,9 & 18.898 & 205 & 10,8 & 218 & 11,5 & -13 & $-0,7$ \\
\hline 10. & Šipovo & 7.973 & 56 & 7,1 & 79 & 9,9 & -23 & $-2,8$ & 9.850 & 107 & 10,9 & 103 & 10,5 & 4 & 0,4 \\
\hline 11. & S.Kupres & 5 & - & - & - & -1 & - & 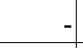 & 188 & 8 & 42,5 & 7 & 37,2 & 1 & 5,3 \\
\hline 12. & Jezero & 533 & 7 & 13,1 & 12 & 22,5 & -5 & $-9,4$ & 1.078 & 11 & 10,2 & 8 & 7,4 & 3 & 2,8 \\
\hline \multicolumn{2}{|l|}{ Total } & 105.834 & 775 & 7,3 & 927 & 8,8 & -152 & $-1,5$ & 115.690 & 1086 & 9,4 & 1195 & 10,3 & -109 & $-0,9$ \\
\hline \multicolumn{2}{|c|}{ in \% of R.Srpska } & $7,6 \%$ & $6,3 \%$ & - & $8,5 \%$ & 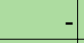 & $11,4 \%$ &  & $7,9 \%$ & $7,7 \%$ & -1 & $9,0 \%$ & - & $11,7 \%$ & - \\
\hline \multicolumn{2}{|c|}{ Republika Srpska } & 1.391 .593 & 12.263 & 8,8 & 10.931 & 7,9 & 1332 & 0,9 & 1.469.182 & 14.127 & 9,6 & 13.153 & 9,0 & 934 & 0,6 \\
\hline
\end{tabular}

Source $9 \mathcal{E} 10$

ats are on the third place in this category, in nine out of ten municipalities. In the municipality of Kupres, they used to own $35.8 \%$ of land, i.e. they came on the second place, right after Serbs (with $58.7 \%)$.

Table 4 refers to the 1996 census of refugees and displaced population, as well as households. There is a considerable portion of refugees (15,301 person) from the municipalities mentioned above in the total number of refugees from Republic of Srpska (3.6\%), although this census did not entirely cover all the refugees. Most of the refugees were displaced into neighboring countries, but some have emigrated overseas. Therefore, we should account for a considerable amount of population who emigrated and now are gradually coming back home. Bigger part of their land is still on the territory of Federation of Bosnia and Herzegovina, and the returning population still has to face some problems with the local administration.

Present migration processes in this area are still characterized by migrations of refugees and population that is returning to their homes, in accordance with Annex no.7 of the Dayton Peace Agreement. In the period from 1992 till 1995, Serbs living in this area experienced genocide and exodus. This fact is confirmed by comparing data from the 1991 census with those from the 1996 census. In 1991, this area was populated with 171,454 Serbs, and by 1996, this number was reduced to 105,819 people, showing that 65,635 Serbs (i.e. $38.3 \%$ )

Table 3 Ethno-demographic structure for twelve municipalities of the northwest part of Republic of Srpska, according to the 1991 census3 and 4)

\begin{tabular}{|c|c|c|c|c|c|c|c|c|c|c|c|c|}
\hline \multirow{3}{*}{\begin{tabular}{|l} 
Ordinal \\
No.
\end{tabular}} & \multirow{3}{*}{$\begin{array}{c}\text { Municipality/area }\left[\mathrm{km}^{2}\right] / \\
\text { number of settlements }\end{array}$} & \multicolumn{5}{|c|}{ Population according to the 1991 census } & \multicolumn{6}{|c|}{$\%$ of settlement area with ethnic majority: Serbs, Croats, Muslims } \\
\hline & & \multirow{2}{*}{$\begin{array}{c}\text { Population } \\
\text { number }\end{array}$} & \multicolumn{4}{|c|}{ Structure in \% } & \multicolumn{2}{|c|}{ Serbs } & \multicolumn{2}{|c|}{ Croats } & \multicolumn{2}{|c|}{ Muslims } \\
\hline & & & Serbs & Croats & Muslims & other & $>50$ & $>66$ & $>50$ & $>66$ & $>50$ & $>66$ \\
\hline 1. & Bos. Dubica/499/ 61 & 31.577 & 69,1 & 1,5 & 20,5 & 8,9 & $60 / 98,0$ & $56 / 89,8$ & $0 / 0,0$ & $0 / 0,0$ & $0 / 0,0$ & $0 / 0,0$ \\
\hline 2. & S.Kostajnica - & & -1 & - & 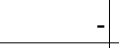 & -1 & - & & - & - & - & \\
\hline 3. & Bos. Novi/554 /60 & 41.541 & 60,4 & 1,0 & 33,9 & 4,7 & $51 / 86,3$ & $51 / 86,3$ & $0 / 0,0$ & $0 / 0,0$ & $7 / 12,9$ & $6 / 11,1$ \\
\hline 4. & Bos. Krupa/780/48 & 58.212 & 23,6 & 0,2 & 74,5 & 1,7 & $25 / 54,5$ & $25 / 54,5$ & $0 / 0,0$ & $0 / 0,0$ & $21 / 41,6$ & $18 / 34,8$ \\
\hline 5. & Sanski Most/984 /75 & 60.119 & 42,2 & 7,1 & 49,0 & 3,7 & $43 / 70,6$ & $40 / 65,4$ & $6 / 6,7$ & $6 / 6,7$ & $21 / 18,2$ & $17 / 5,4$ \\
\hline 6. & Ključ/850/ 61 & 37.233 & 49,4 & 0,9 & 47,5 & 2,2 & $41 / 80,4$ & $39 / 75,2$ & $0 / 0,0$ & $0 / 0,0$ & $20 / 19,6$ & $17 / 17,2$ \\
\hline 7. & Bos. Petrovac/853/35 & 15.552 & 75,2 & 0,3 & 21,1 & 3,4 & $32 / 96,1$ & $32 / 96,1$ & $0 / 0,0$ & $0 / 0,0$ & $2 / 2,3$ & $1 / 1,3$ \\
\hline 8. & Titov Drvar/950/38 & 17.079 & 97,3 & 0,2 & 0,2 & 2,3 & $38 / 100$ & $38 / 100$ & $0 / 0,0$ & $0 / 0,0$ & $0 / 0,0$ & $0 / 0,0$ \\
\hline 9. & Mrkonj. Grad/679/ 38 & 27.379 & 77,3 & 7,8 & 12,0 & 2,9 & $34 / 89,7$ & $34 / 89,7$ & $2 / 2,4$ & $1 / 2,4$ & $2 / 5,2$ & $1 / 2,1$ \\
\hline 10. & Šipovo/470/ 40 & 15.553 & 79,2 & 0,2 & 19,3 & 1,3 & $36 / 93,8$ & $32 / 84,2$ & $0 / 0,0$ & $0 / 0,0$ & $4 / 6,2$ & $1 / 0,9$ \\
\hline 11. & Kupres/622/ 36 & 9.663 & 50,7 & 39,6 & 8,4 & 1,3 & $17 / 57,6$ & $16 / 56,4$ & $15 / 37,3$ & $13 / 33,8$ & $2 / 3,3$ & $1 / 1,0$ \\
\hline 12. & Jezero/- & 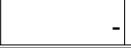 & - & - & -1 & -1 & - & -1 & -1 & -1 & -1 & \\
\hline
\end{tabular}




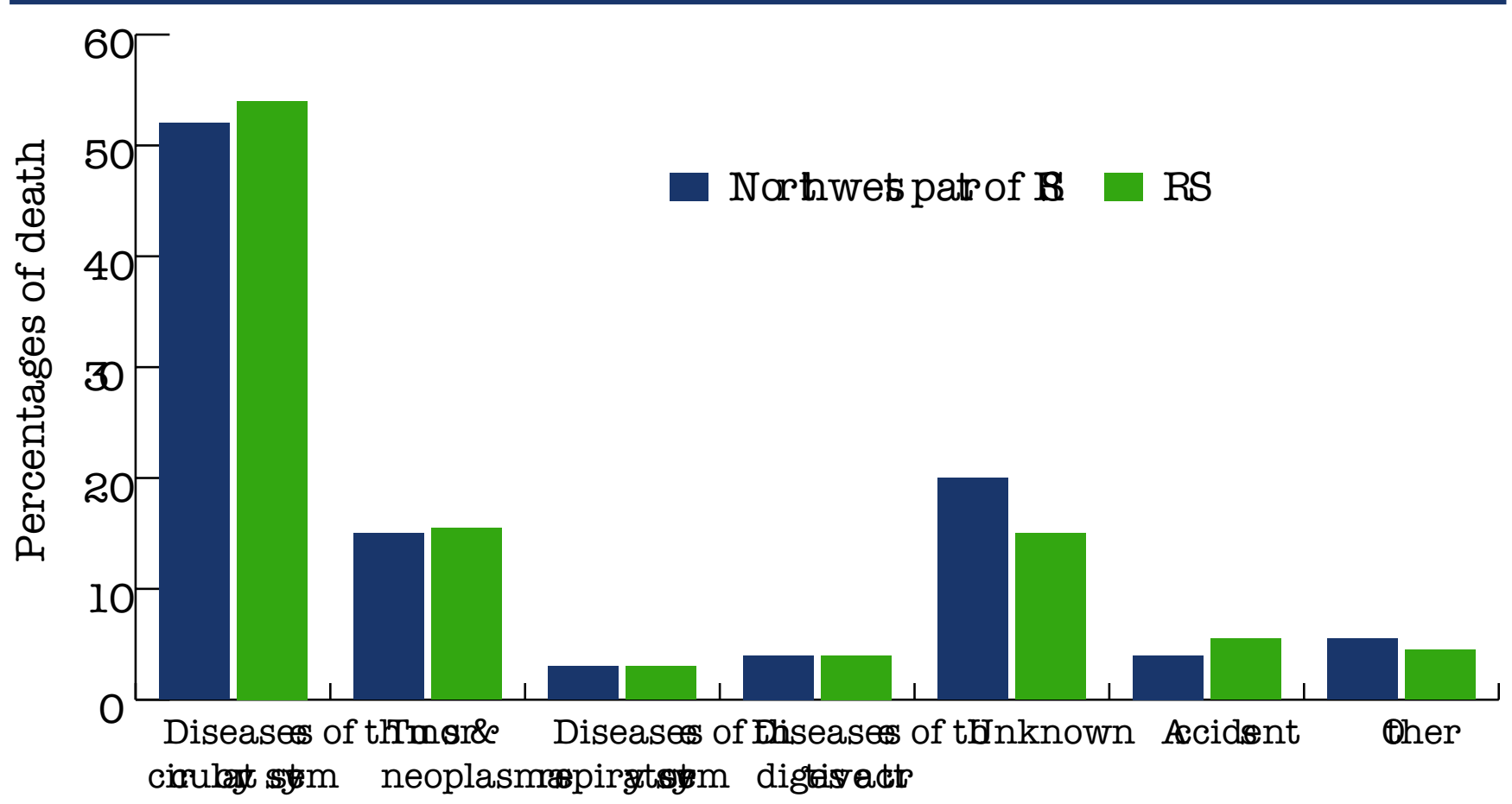

Graph 1 Main causes of deaths in Republic of Srpska and its northwest part

were gone. The exodus lasted for three years of war. The army of Muslim Croatian Federation, regular army of Republic of Croatia and paramilitary units of Muslims, Croats and mercenaries (mujahideens and others) committed many atrocities among Serbian people. The most intensive exodus and genocide happened in the second half of 1995, when entire Serbian population was expelled from this area.

Number of household members in these municipalities is near the Republic average (3.4 members), although this area used to be known through centuries for its high birth rate.

\section{Potentials and \\ Perspectives}

Data show that the economic activities play a far more important role in these municipalities than the non-economic ones. Within Republic of Srpska, economic activities of this area make up $9.3 \%$, while non-economic ones make up $6.9 \%$. The most important economic activities are industry (with 8,598 em- ployees) and forestry (with 2,060 employees), which is in accordance with the natural resources in this area. Forestry of this area makes up $33.5 \%$ of forestry in Republic of Srpska. According to the Statistical Yearbook of SR Bosnia and Herzegovina, in 1990, there were 62,043 employees in the area, which is by $66.7 \%$ more than in 1999 .

Institute of Economics in Banja Luka made a research on relative development level of municipalities in 1999. Taking into account various factors (employment, income, health care, number of

Table 4 Permanent population and refugees, households and number of members for twelve municipalities of the northwest part of Republic of Srpska, according to the 1996 census

\begin{tabular}{|c|c|c|c|c|c|c|c|c|c|c|}
\hline \multirow{2}{*}{$\begin{array}{l}\text { Ordinal } \\
\text { number }\end{array}$} & \multirow{2}{*}{ Municipality } & \multicolumn{3}{|c|}{ Population number } & \multicolumn{3}{|c|}{ Households number } & \multicolumn{3}{|c|}{ Average number of members } \\
\hline & & Total & Refugees & Permanent & Total & Refugees & Permanent & Total & Refugees & Permanent \\
\hline 1. & Koz.Dubica & 33.289 & 3.864 & 29.425 & 9.812 & 1.160 & 8.652 & 3,39 & 3,33 & 3,40 \\
\hline 2. & S.Kostajnica & 7.467 & 1.450 & 6.017 & 2.201 & 608 & 1.593 & 3,39 & 2,38 & 3,78 \\
\hline 3. & Novi Grad & 28.502 & 6.421 & 22.081 & 8.401 & 2.122 & 6.279 & 3,39 & 3,03 & 3,52 \\
\hline 4. & Krupa na Uni & 1.615 & 839 & 776 & 476 & 276 & 200 & 3,39 & 3,04 & 3,88 \\
\hline 5. & S.S.Most & 2.463 & 271 & 2.192 & 726 & 82 & 644 & 3,39 & 3,30 & 3,40 \\
\hline 6. & S.Ključ & 7.881 & 50 & 7.831 & 2.323 & 16 & 2.307 & 3,39 & 3,13 & 3,39 \\
\hline 7. & Petrovac & & - & & -1 & & & - & & \\
\hline 8. & S.Drvar & 3 & - & 3 & 1 & - & 1 & 3,0 & - & 3,0 \\
\hline 9. & Mrkonj. Grad & 16.088 & 668 & 15.420 & 4.742 & 207 & 4.535 & 3,39 & 3,23 & 3,40 \\
\hline 10. & Šipovo & 7.973 & 1.733 & 6.240 & 2.350 & 573 & 1.777 & 3,39 & 3,02 & 3,51 \\
\hline 11. & S.Kupres & 5 & 5 & - & 2 & 2 & - & 2,50 & 2,50 & 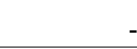 \\
\hline 12. & Jezero & 533 & - & 533 & 157 & - & 157 & 3,39 & - & 3,39 \\
\hline \multicolumn{2}{|l|}{ Total } & 105.819 & 15.301 & 90.518 & 31.191 & 5.046 & 26.145 & 3,39 & 3,0 & 3,46 \\
\hline \multicolumn{2}{|c|}{ in \% of R.Srpska } & $7,6 \%$ & $3,6 \%$ & $9,3 \%$ & $7,6 \%$ & $3,8 \%$ & $9,4 \%$ & & & - \\
\hline \multicolumn{2}{|c|}{ Republika Srpska } & 1.391 .593 & 419.879 & 971.714 & 410.173 & 132.298 & 277.875 & 3,39 & 3,17 & 3,49 \\
\hline
\end{tabular}

Source 1, $p p$ 49-50 
phones and cars, agriculture, etc.) they made the following categories. Developed municipalities are Kozarska Dubica and Mrkonjić Grad. Moderately developed municipalities are Srpska Kostajnica and Novi Grad. Undeveloped municipality is Sipovo, and seven municipalities are extremely undeveloped: Krupa na Uni, Srpski Sanski Most, Srpski Ključ, Srpski Petrovac, Srpski Drvar, Srpski Kupres and Jezero (7.7).

Developmental potentials of this area are forestry, mining, cattle breeding, spa tourism (spas of Mlječanice and Lješljani with thermo-mineral water), clear natural water (springs of Pliva and Janjski Otoci), lakes (Balkana) and hunting and fishing tourism.

\section{Conclusion}

Twelve municipalities in the northwest part of Republic of Srpska have a periphery geographic position with respect to leading social and economic centers. This territory has a rather low population density and its portion in the population of Republic of Srpska is less than $8 \%$. Like the majority of others, these twelve municipalities have low natural increase which is a consequence of low natality rate and high mortality rate. Considerably high mortality rate is a consequence of war, emigration, and genocide (total number of victims is still not defined, because there are some masstombs which were discovered only lately). Serbs have absolute domination in this area and they own most of the land. However, the largest part of the land has stayed on the territory of Federation of Bosnia and Herzegovina. Local population, returning to their homes, should be able to restore their rights to that land. The most prominent form of migration is still migrations of refugees, which will be a decisive factor for the future demographic and social development of this area. If the refugees return and if the destroyed infrastructure is built up again, this area could develop quickly in the future. Further perspectives of these municipalities will depend on the return of population, reparation of infrastructure and cattle fond, privatization process, improvement of tourism, as well as protection of forests and ecosystems of the area.

Important questions are economic self-preservation of the area, planned development and exploitation of natural resources (for example, today we are witnessing unplanned wood exploitation in this area). Without major financial input, this area will not be able to achieve economic self-preservation. What we need is a precise and longterm development plan, which would create the conditions for fast integration of this area in the modern Europe.
References

1. Špirić N., Marijanac Z. Stanovništvo RepublikeSrpske. Banja Luka:Univerzitet u BanjojLuci Ekonomski fakultet, Prirodno-matematički fakultet; 1999.

2. Marijanac Z., Marinković D. Neke osnovne demografske strukture i problemi stanovništva Republike Srpske. Beograd: Zbornik radova geografskog fakulteta; 2001.

3. Jakšić D. Postdejtonska stvarnost i perspektive. Banja Luka: Ekonomski institut; 1996.

4. Jakšić D. Republika Srpska - stanovništvo, prostor, resursi. Banja Luka: Ekonomski institut; 1995.

5. Marijanac Z. Razvitak stanovništva Bosne i Hercegovine. Banja Luka: Matica srpska Republike Srpske; 2000.

6. Prostorni plan Republike Srpske. Banja Luka: Republički urbanistički zavod; 1994.

7. Relativni nivo razvijenosti opština u 1999. godini. Banja Luka: Ekonomski institut u Banjoj Luci; 2000.

8. Statistički godišnjaci. Sarajevo: Republički zavod za statistiku; 1981-1991.

9. Demografska statistika (brojevi 1,2,3 i 4). Banja Luka: Republički zavod za statistiku RS; 1999-2001.

10.Saopštenja Republičkog zavoda za statistiku. Banja Luka: Republički zavod za statistiku RS; 1999-2000. 